\title{
Religious Education As Developmental Tool In 21st Century Africa
}

\author{
Nwamah Grace Ozioma \\ Department of Religious Studies,Imo State University, Owerri
}

\begin{abstract}
The near absence of moral values appears to be responsible for most of the troubles bedeviling the African continent. For instance, Nigeria political and socio-economic woes are due largely to the lack or near absence of moral values. This paper articulates the potentiality of religious education to drive development in this $21^{\text {st }}$ century Africa. The study uses the qualitative research approach which relies on argumentation that rigorously and strictly adheres to the rules of logical syllogism and coherence. The findings indicate that education is a determinant factor for the development of any nation or society. Again, the study found that right values and morals are adequately integrated in educational system through religious teachings. The study demonstrates that the change of the human person through re-emphasis on moral values is a prerequisite for the development of $21^{\text {st }}$ century Africa and reveals that no nation can rise above the quality of her educated citizenry. The paper concludes that 21 st century Africa can be mobilized and inspired towards using religious education to drive development in the continent.
\end{abstract}

Keywords: Religious Education, Moral Values, Development and $21^{\text {st }}$ Century Africa

\section{BACKGROUND TO THE STUDY}

In our world today, there is one concept that has been greatly blamed for the failure of virtually all things. All forms of ills are seemingly attributed to its presence. It has been blamed for the destruction of the political, socio - economic and cultural life of many societies. It is noted to stunt growth and development. It destroys ethical and democratic values, creates political instability and undermines the integrity of the state. This vice encourages and promotes crimes and large scale fraud. It concentrates wealth in the hands of a few individuals and promotes widespread poverty and large scale unemployment. There is hardly any sector of life that is not affected by this malaise that promotes inflation and destroys the efficiency of public institutions. It is at present, one of the major challenges to sustainable development the world over.At this point, everyone can guess what this concept is. It has been called a serious crime, which undermines the Rule of Law, makes economic planning difficult if not impossible and creates unjust and inequitable environment. It has been identified as perhaps the most cancerous of Nigeria's myriad of afflictions. Presently, the entire world, in particular, $21^{\text {st }}$ Century Africa is bedeviled by this malaise. Its name is corruption. The following is said of it: With corruption there can be neither sustainable development nor political stability. By breeding and feeding on inefficiency, corruption invariably strangles the system of social organization. In fact, corruption is literally the antithesis of development and progress. (Obasanjo, 2000).

Certainly, when a problem becomes identifiable, it makes solution to it easy and attainable. Nigerian government like other governments in the African continent and government in other continents of the world have employed various means to end corruption but to no avail. The list of the efforts of government at curbing corruption both at the military and democratic dispensations in Nigeria is endless. For example, 'The corrupt practices Decrees' was promulgated in 1975, 'War Against Indiscipline' (WAI) program was launched March 1984, the 'Code of Conduct Bureau and Tribunal Act' 1990, 'Independent Corrupt Practices and Other Related Offences Commission' (ICPC) September 2000 to mention but a few.

Corruption has taken its toll in $21^{\text {st }}$ century Africa. Recently, GIZ (2015) reported that the Kenyan State loses four billion US dollars to corruption every year - anywhere from 25 to 30 percent of the total state budget. This situation is clearly affecting both the foreign and domestic investment climate as highlighted by the nongovernmental organisation Transparency International. In Ghana, Anas AremeyawAnas one of Africa's most intrepid undercover journalists has exposed several cases of corruption in Ghana. The situation of corruption in Ghana according to anti-graft campaigners is said to be worsening. Nigeria, Ivory Coast, South Africa, Zimbabwe and many other African countries share similar plights. Indeed, the phenomenon of corruption has become pervasive and continues to weaken the moral fiber of the African continent.Giving this backdrop, it becomes clearer that corruption has been the greatest challenge to sustainable development in the $21^{\text {st }}$ century Africa. Any developmental tool that is effective and can drive development in the continent must be such that is 
particularly viable in tackling the problems of corruption. Thus, in a bid to revitalize a society already bedeviled with various degenerating ills, religious education becomes our focus.

\section{Conceptual Literature \\ 2.1 Religious Education}

Religious education as instruction in religion is a subject of general education. It has been described as an education in a school which places a strong emphasis on the beliefs associated to a particular religion. This paper define religious education as the act of teaching people, especially students about the tenets, doctrines and values of a religion with the aim of guiding them to imbibe the moral principles and ethical standards which will help them to become well-meaning members of the society.Education is a determinant factor for the development of any nation or society. According to Igwe cited in Igwe, Saheed \& Olufemi (2013:11), "educational planners and administrators have consistently expressed the view that education is not only a costly venture but also that no nation can rise above the quality of her educated citizenry". Education happens to be one of the three known methods by which people may seek to solve the world's problems. The other two are revolution and war. In its nature, education

works slowly, in an evolutionary manner. It creates no sudden utopias. It offers no magic remedies. It gives no categorical promises. It demands effort and discipline. It awakens man to his own creative possibilities. Education, rightly considered, is man's most formidable tool for survival (Ilori, 2013:113).

It is for this reason that Schreiner (2005:11) clarifies that "a quite often mentioned attainment target for education is to encourage tolerance and respect for the culture of others". The education that has the potential to do all that Schreiner recommends is among others, -religious education. Good-quality religious education can transform pupils' assessment of themselves and others, and their understanding of the wider position of the world in which we live (Qualification and Curriculum Authority, 2004).Religious education teaches about religion in its broadest sense, about religions, and about religious diversity in the world. It is not to be seen as religious instruction which is a programme of instruction that aims at providing information regarding a particular set of religious beliefs with a view to promoting adherence thereto. It (religious instruction) has as focus to promote adherence to a specific faith/belief. Religious education does not promote any particular religion. It is a programme for studying about religion in many forms, as an important dimension of human experience and a significant subject field in the school curriculum (Engeberton,de Souza, Durka \& Gearon 2010).Religious education pursues a balanced approach to teaching and learning about religion. It provides opportunity for both a deeper sense of self-realization and a broader civil acceptance of others. It balances the familiar and the foreign in ways that give individuals new insight into both. Religious education can facilitate the development of both empathetic appreciation and critical analysis (Engeberton et al 2010). It teaches the individual about a world of religious diversity, but at the same time it encourages one to think in terms of national unity. Prothero, (2007:22) refers to it as "the ability to understand and use in one's day-to-day life the basic building of religious traditions - their key terms, symbols, doctrines, practices, sayings, characters, metaphors, and narratives". The teaching of the role of religion in history, society and the world can indeed be an important part of a well balanced and complete education.People's spiritual, moral, social and cultural development is promoted through religious education. Also, religious education prepares the individual for the opportunities, responsibilities and experiences of life. For the fact that the focus of religious education is on the ultimate questions and ethical issues, it seeks to develop people's awareness of themselves and others. Kowino, Agak \& Kochung (2012) have shown how religious education develops willingness in learners to value diversity in religion and culture. This attitude, thus, enables the individual to explore more about other people's religious and cultural beliefs and compare with theirs. It discourages the attitude of rigidly following one's own religious and cultural beliefs and practices.Religious education has a way of broadening the learner's way of thinking and instilling self confidence. It provides moral guidance and encourages people to improve their lives. In religious education lessons, pupils learn to become more broadminded, to accept other people's beliefs and faiths and not to let race or religion come in the way of what they see in an individual.

\subsection{Development}

For almost every writer, a different definition of development exists. As a concept, development has a wide connotation. "Development too is a multidimensional phenomenon which can be seen from many points of view" Peterson (1987:7). It is said to include man, environment, material as well as infrastructure. In the past, development was first seen in terms of economic growth only. But before long, development focused on social development and then socio-economic development. In the 1960s, the discussion vacillated around human or human-centred development, the provision of basic needs, and endogenous and participatory development. In the 1980s, the combination of development thinking and environmental movement was reflected in the term "sustainable development," coined by the Bruntland Commission (World Commission for Sustainable Development, 1987). In the 1990s, as though reflecting on 40 years of failure, the United Nations held an 
unprecedented number of world conferences on children, human rights, population, women, environment, social development, human settlements and food, which generated political commitment and international agreement on a number of issues. Non-governmental and community-based organizations exploded in numbers as a byproduct of the preparation for and participation in these conferences.Today, development is not purely an economic phenomenon but rather a multi-dimensional process involving reorganization and reorientation of entire economic and social system" (Todaro, 2015). Development as Todaro further explains is a process of improving the quality of all human lives with three equally important aspects. These are: i). raising people's living levels, i.e. incomes and consumption, levels of food, medical services, education through relevant growth processes. ii). Creating conditions conducive to the growth of peoples' self-esteem through the establishment of social, political and economic systems and institutions which promote human dignity and respect. iii). Increasing people's freedom to choose by enlarging the range of their choice variables, e.g. varieties of goods and services.Ejizu (2008:50) likened the development of a country to that of an animate organism, using the analogy of living organism. The scholar showed that the development of each part is important, but not all of equal importance. He placed the parts of development under primary and secondary importance, and further emphasized that while the primary corresponds to the human dimension, the secondary aspect corresponds to the infra-human dimension; things like land, natural resources, roads, machines, buildings etc. The human dimension is of primary importance and needs proper development. Omoregbe (2000:147) affirms that "the most important aspect in the development of a human person is his moral development". This is particularly true as the scholar persuasively argues that the "moral development of citizens must precede other aspect of the development otherwise the process of development would be obstructed by the immorality of the citizens". Moral development indeed, is an indispensable condition for the development of any nation. Falade (2015:149) rightly pointed out that "education which is a lifelong process is a tool for human moral development". The education that is known to be competent of moral development is religious education.

Development is a continuous process of positive change in the quality and span of life of a person or group of persons. Religious education is capable of producing an individual who can become a change agent that sustainable development requires. With religious education, $21^{\text {st }}$ century Africa can achieve the development that meets the needs of the present without compromising the ability of future generations to meet their own needs.

\subsection{Religious Education as an agent of Development in Africa}

From the beginning, this writer has pointed out corruption as the major problem hindering sustainable development in $21^{\text {st }}$ century Africa. As complex as the problem of corruption is, it has to be observed that it is largely perpetrated by human beings. What this means is that the African continent have human problems. As a continent, Africa is blessed with numerous natural and mineral resources, but having human problems. The change of the human person therefore, becomes a contemporary issue and challenge in African development patterns. This change is possible because it is worthwhile and transformative. Change here, must not be seen in the context of political economic and social change. It is not change in government policies or political ideologies. It is not a change from one political party to the other. It is not a political party slogan like the Nigeria 'All Progressive Congress (APC) adopted. Change is a complex-whole. The great educators of the past like Socrates, Erasmus and Tolstoy have pointed out that change must come from within and that it must be based on ethical principles. This is the kind of change that this paper proposes. When the human person is changed from within, every other thing around him/her will change naturally.

Achebe (1984) had pointed out before now, that "the trouble with Nigeria is simply and squarely a failure of leadership". This presupposes change. But, as true as Achebe's assertion is, leadership in Nigeria has changed hands severally since 1984 with little observable change seen in the society. Today, the problem with Nigeria and all of Africa is no longer that of leadership even though it is part of it. The problem is not only poverty, corruption, failed infrastructures, bad roads etc. The problem is as this paper has identified a human problem. If the human person is morally developed or transformed, the African continent will definitely develop. The primary gap in development of the African continent is fearless moral leadership. It is religious education that forms this attribute into the human person.

$21^{\text {st }}$ century Africa can drive development using religious education. This is possible, through an extensive teaching of morals - good morals, from the grassroots. Good moral lessons will change the individual. It is a known fact that religious education actively promotes values of truth, justice, respect for all and care of the environment. It places specific emphasis on pupils valuing themselves and others. For instance, it is through religious education that the individual learns that he has specific obligation to himself, to his fellow human beings and to the society to which he belongs. It moulds the human character and life in a way that enables the individual and the society at large to experience growth and development.Religious education is a viable tool for the development of $21^{\text {st }}$ century Africa. It must be understood that the present writer is not unaware of the fact that religious education is not a new trend in the African educational system. But, there is need for a 
reformation. Africa as a deeply religious people must seek to explore the potential of religion for the transformation of the individual and the society. Given the conditions of African religiosity, it is felt that religion must have already played a constructive role in shaping positive attitudes and approaches related to different area of life. However, from the perspective of religious education, human being has a spiritual nature which is the source of such motivation as showing forth love, seeking truth and desiring to serve others. Consequently, if one were to approach development from a spiritual perspective, one will uphold the values of cooperation, reciprocity and concern for others rather than competition and pursuit of self interest. Such behaviour in turn, would led to a change in the way development activity is conceived.Religion brings order in the society. A well ordered society provides serene atmosphere for development to thrive. Religious education can give $21^{\text {st }}$ century Africa a well-organized and conducive environment for her development. Durkheim's (1961) presentation affirms that where there is religion in practice, morality abounds and this becomes the source of security for the members of that society. Kowino, et al (2012), explains further that "the need to keep this order whether social, economic or political is what has made every society to ensure that spiritual insights are developed in the youths" (p. 154). The means of development of spiritual insights in these youths is through Religious education. Religious education brings order in human society by placing specific emphasis on the role of family and the community in religious belief and activity. Also, religious education ensures orderliness by placing emphasis on the celebration of diversity in society through understanding similarities and differences.

Religious education is also committed to exploring the significance of the environment, and the role of human beings within it. A central concern of religious education is the promotion of pupil's self-worth. A sense of selfworth helps pupil's to reflect on their uniqueness as human beings, share their feelings and emotions with others and appreciate the importance of forming and maintaining positive relationships. Through the promotion of selfworth, religious education can produce fearless moral leadership in this $21^{\text {st }}$ century Africa. As soon as this is done, religious education has successfully, succeeded in filling the primary gap in development.

\subsection{Conclusion}

If there should be sustainable development in $21^{\text {st }}$ century Africa, it is important for the continent to look in the direction of religious education. This is because religious education is a change agent. The change of the human person is identified in this study as a contemporary issue and challenge in African development patterns. This change is possible because it is worthwhile and transformative.21st century Africa's challenge calls for innovative strategies to address the problem comprehensively. The crisis in Africa is not just about insurgence. It is also about other forms of violence like absence of social security (unemployment, lack of access to healthcare provision and education, environmental degradation, etc), ethnic and inter-communal strife and perennial violence arising from criminal activities. All these emanate from economic deprivations and inequalities which the absence of moral values that had given way to large-scale corruption created. Moral values are the standard of good and evil which govern an individual's behaviour and choices. Religion is a major source of moral values. No known religion is devoid of moral and ethical principles.

Indeed, religion is a force which has mostly influenced the character of mankind. Man's ethical standards, his moral behaviours and standard of judgment appears to be products of his religious training. This implies that religious education for sustainable development is a step in the right direction. This paper thus maintains that development can be enriched by the insights offered by religion, faith, spirituality and values. The conclusion is that $21^{\text {st }}$ century Africa can be mobilized and inspired towards using religious education to drive development in the continent.

\subsection{Recommendations}

This study recommends that religious education be encouraged and re-emphasized at all levels of education in order to facilitate the change of the human person through its emphasis on human moral development.

\section{REFERENCES}

[1] Achebe, C. (1984), "The Trouble with Nigeria". London: Heinemann.

[2] Alkira, S. (nd), "Religion and Development".

Retrieved http://www.ophi.org.uk/wp-content/uploads/Alkire-Religion-Devt.pdf

[3] Alolo, N. A. (2007), "Religions and Development Research programme [working paper 17] African traditional religion and the concepts of Development: A Background Paper". International Development Department, University of Birmingham. Retrieved from http://www.rad.bham.ac.uk

[4] Ejizu, C. I. (2008), "Between Religion and Morality: Their inter-Connection and Significance in Public Life". A University of Port Harcourt Inaugural lecture[Inaugural lecture series] no.59. March, 13.

[5] Engebretson, K., de Souza, M., Durka, G., \& Gearon, L. (Eds.) (2001), "International Handbook of Interreligious Education Part 1". London: Springer Dordrecht Heidelberg. 
[6] Falade, D. A. (2015), "Christian Religious knowledge and the Teaching of Moral values in the Nigeria Junior Secondary Schools: Problems and prospects". American International Journal of Research in Humanities, Arts and Social Sciences 9(2) 148-151.

[7] GIZ, (2015), "Supporting Good Governance to strengthen Integrity and Accountability in Kenya". German Federal Ministry for Economic Corporation and Development/Kenyan Ministry of Justice.[Project Report]. Retrieved from https://www.giz.de/en/worldwide/24981.html

[8] Harper, S. (Ed.) (2000), "The lab, the Temple and the Market: Reflections at the Intersection of science, Religion and Development". Canada: International Development Research Centre

[9] Igwe, R. O., Rufai, S. A., \&Olufemi, A. G. (2013), "Social Reconstruction through Religious Education: A survey on Nigeria". Humanities and Social Science Journal 8(1), 10-18

[10] Ilori, A. J. (2013), "Philosophy of Christian Education: An African perspective". Plateau: African Christian Textbooks.

[11] Institute for Studies in Global Prosperity, (2010), "Science, Religion and Development: Promoting a discourse in India, Brazil and Uganda". [Occasional Paper]. Retrieved from www.globalprosperity.org

[12] Karamouzis, P. (2009), "Religions, Education and Democracy: The Necessity of Inter-religious Education in the Modern Public School System". ПолитикологијаРелигије 1(III), 111-125.

[13] Kowino, J. O., Agak, J. O., \& Kochung, J.E. (2012), "The Perceived Mismatch between the Teaching of Christian religious Education and learner Acquisition of Spiritual insights in Kenyan secondary schools". International Journal of Academic Research in Progressive Education and Development, 1(2), 153-176.

[14] Marshall, K. (2001), "Development and Religion: A Different lens on development Debates". Retrieved from www.jstor.org/stable/1493254

[15] Mersland, R., D'Espallier, B., \& Supphellen, M.(2012), "The Effects of Religion on Development efforts evidence from the Microfinance Industry and a Research Agenda". World Development, 1-12. doi: 10.1016/j.worlddev.2012.05.030

[16] Obasanjo, O. (2000), "President Olusegun Obasanjo's Speech at the Inauguration of the Independent Corrupt Practices and other related offences Commission [ICPC]". September 29.

[17] Omoregbe, J. I. (2000), "Ethics, a Systematic and Historical Study". Lagos: Jajo Educational Research and Publishers.

[18] Peterson, K. H. (1987), "Religion, Development and African Identity". Seminar Proceedings no. 17, Scandinavian Institute of African Studies, Uppsala

[19] Prothero, S. (2007), "Religious literacy". San Francisco: Harper San Francisco Qualification \& Curriculum Authority, (2004), "Religious Education: The Non-Statutory National Framework". London. Retrieved from www.qca.org.uk

[20] Schreiner, P. (2005), "Religious Education in Europe". Comenius Institute Germany: ICCS. Retrieved from resources.eun.org

[21] Tadora, S. (2015), "The Concept of Development: Definitions, Theories, and Contemporary perspectives [PowerPoint Slides]". Retrieved from www.uky.edu

[22] Tomalin, E. (2007), "Religions and Development Research programme: [Working Paper 4]Sociology, Religion and development: Literature Review". International Development Department, University of Birmingham. Retrieved from http://www.rad.bham.ac.uk

[23] William, F. R. (2000), "The lab, the Temple and the Market: Expanding the Conversation". Retrieved from http://idl-bnc.idrc.ca/dspace/bits.../117205.pdf 